\title{
TRADISI MITOS SANGKAL DALAM PERTUNANGAN DINI PERSPEKTIF KIAI DI MADURA
}

\author{
Iwan Kuswandi, Lilik Fadilatin Azizah \\ Sekolah Tinggi Keguruan dan Ilmu Pendidikan (STKIP) PGRI Sumenep \\ Email: iwankus@stkippgrisumenep.ac.id
}

\begin{abstract}
:
The article analyzes the early fiancé in Kiai (Muslim scholar) perspective and describes how the Kiai assesses public confidence in the myth of tako sangkal in early fiancé tradition. This research is a qualitative study with the case in Pragaan Sumenep, East Jawa. Data are collected by using the participatory observation and interview method and then analyzed by using Miles and Huberman's model. This article finds out that Kiai in Pragaan agreed that early fiancé is not contradictive to Islamic law. But there is Kiai opined that the blessing parents are one of the fiancé terms, but the other one said that the daughter has the right to choose a partner. In this context, the myth of tako sangkal in early tradition fiancé is not violating Islamic law so that it is a habit in their community.
\end{abstract}

Keywords: Sangkal, early fiance, Kiai, Madura.

\section{Abstrak:}

Artikel ini menganalisis tunangan awal dalam perspektif Kiai dan menjelaskan bagaimana Kiai menilai kepercayaan publik terhadap mitos tako sangkal dalam tradisi tunangan awal. Penelitian ini merupakan studi kualitatif dengan kasus di Pragaan Sumenep, Jawa Timur. Data dikumpulkan dengan menggunakan metode observasi partisipatif dan wawancara, dan kemudian dianalisis dengan menggunakan model Miles dan Huberman. Artikel ini menemukan bahwa Kiai di Pragaan setuju bahwa tunangan awal tidak bertentangan dengan hukum Islam. Tetapi ada Kiai yang berpendapat bahwa restu orang tua adalah salah satu syarat tunangan, tetapi yang lain mengatakan bahwa anak perempuan itu memiliki hak untuk memilih pasangan. 
Dalam konteks ini, mitos tako sangkal dalam tradisi awal tunangan tidak melanggar hukum Islam sehingga menjadi kebiasaan di komunitas mereka.

Kata Kunci: Sangkal, Pertunangan Dini, Kiai, Madura.

\section{Pendahuluan}

Tradisi pertunangan anak usia dini merupakan bagian dari budaya lokal yang membuat banyak orang menyimpulkan bahwa masyarakat Madura adalah masyarakat yang sukses membentuk kepatuhan seorang anak kepada orang tuanya. Dalam ajaran Islam, seorang anak harus memiliki adab yang baik terhadap orang tuanya, mendengarkan perkataannya, mematuhi perintahnya, serta yang terpenting, selalu berusaha mendapat keridaannya. Hal ini sebagaimana disabdakan Rasulullah bahwa, "Rida Allah terletak pada rida kedua orang tua dan murka-Nya terletak pada kemurkaan keduanya.” Bagi masyarakat Madura, kepatuhan terhadap orang tua mengalahkan kepatuhan seorang murid terhadap gurunya, dan kepatuhan rakyat kepada pemerintahnya. Untuk itu, di Madura ada filsafat hidup bhuppa' bhâbhu' ghuru rato (patuh kepada orang tua, guru dan pemerintah).

Keselarasan seruan Islam dan pandangan hidup orang Madura telah memposisikan orang tua bagi seorang anak begitu mulia. Hal ini merupakan bukti nyata bahwa nilai Islam benar-benar menjadi nafas bagi kehidupan orang Madura. Assegaf menyatakan bahwa agama mempengaruhi masyarakat, dan demikian juga masyarakat mempengaruhi agama, atau terjadi interaksi yang dinamis. ${ }^{1}$ Pencitraan sosok Madura selalu diidentikkan dengan Islam. Agama Islam yang sudah "merasuk" sedemikian kuat akhirnya berfungsi sebagai inti kebudayaan yang memuat ajaran moral dan etika yang menyelimuti seluruh kehidupan masyarakat Madura. Kuatnya Islam dalam kehidupan orang Madura ini kemudian melahirkan kepatuhan yang tinggi terhadap apa yang diperintahkan oleh Islam.

Salah satu contoh kepatuhan anak terhadap orang tuanya terjadi pada kasus pertunangan dan perjodohan seorang anak. Kasus yang terjadi pada masyarakat di Kecamatan Pragaan Kabupaten Sumenep bahwa di daerah ini marak terjadi pertunangan usia dini yang banyak dialami oleh anak usia Sekolah Dasar, antara umur 6-12 tahun. Hasil observasi awal yang dilakukan peneliti memperlihatkan bahwa banyak terjadi prosesi pertunangan, yang melibatkan

\footnotetext{
${ }^{1}$ Abd Rachman Assegaf, Desain Riset Sosial-Keagamaan: Pendekatan Integratif-Interkonektif. (Yogyakarta: Gama Media. 2007), hlm. 60.
} 
anak usia SD. Sebagai contoh, ada salah seorang anak bernama, Nur Izzah, warga asal Kecamatan Pragaan. Menurut pengakuannya, dia bertunangan saat masih duduk di bangku Sekolah Dasar. Kebetulan saat itu, dirinya masih mengenyam pendidikan di pesantren. Saat ibunya menjenguk ke pesantren, tiba-tiba ibunya menyodorkan emas cincin, katanya dari tunangannya. Tanpa pertanyaan panjang, Nur Izzah pun memakai cincin tersebut. Selama bertahun-tahun, Nur Izzah pun tidak mengerti apa makna tunangan. Ia baru sadar saat duduk di bangku Sekolah Menengah Atas, bahwa ternyata tunangannya adalah saudara sepupunya sendiri. Kasus ini merupakan di antara bukti bahwa anak perempuann di Madura memiliki tingkat kepatuhan yang tinggi kepada orang tuanya.

Bagi masyarakat Madura, pertunangan yang terjadi umumnya bukan untuk menandai telah dekatnya waktu pernikahan, akan tetapi lebih pada menandai ikatan antara seorang perempuann dan lelaki. ${ }^{2}$ Pertunangan lama bagi masyarakat Madura sudah menjadi hal biasa. Karena bagi orang Madura, pertunangan merupakan "tanda" bagi seorang perempuann bahwa dia sudah memiliki calon suami. Seorang tokoh agama di desa Prenduan Kecamatan Pragaan, Kiai Muhammad Syamrawie menuturkan bahwa di daerahnya sudah umum terjadi pertunangan usia dini, walaupun proses pernikahannya baru dilaksanakan lebih dari lima tahun kemudian. Hal ini bertujuan untuk memberi tanda bahwa anak tersebut sudah memiliki calon suami.

Menurut penuturan Ibu Mailah, salah seorang orang tua pelaku pertunangan, saat ini anaknya masih duduk di kelas 5 madrasah ibtidaiyah. Anaknya bertunangan karena sudah ada lelaki yang sudah melamar. Melakukan penolakan terhadap lamaran yang disebut tako' sangkal akan berdampak buruk pada anak perempuannnya. Mitos yang banyak diyakini di masyarakat Pragaan adalah bahwa lamaran pertama yang ditolak akan berdampak pada si perempuann yang bisa tidak cepat mendapat jodoh, sehingga akan kesulitan mendapatkan jodoh sampai tua. Dalam istilah masyarakat Pragaan mitos ini disebut tako' sangkal, yaitu sebuah pamali berarti takut ditimpa kesialan, sehingga akan menjadi perempuan tua. Hasil kajian yang dilakukan oleh Erma Fatmawati menegaskan bahwa bagi orang tua masyarakat Madura generasi sebelum tahun 1970 an, lamaran pertama kali terhadap anak perempuann harus diterima. Suka atau tidak suka. Penolakan dapat berdampak negatif pada si perempuann. Dia bisa tidak cepat mendapat jodoh hingga menjadi perempuan tua. ${ }^{3}$

${ }^{2}$ Masyithah Mardhatillah, "Perempuann Madura sebagai Simbol Prestise dan Pelaku Tradisi Perjodohan”, Jurnal Musawa, Vol 13, No. 2, 2014, hlm. 167-178.

3 Erma Fatmawati, "Pernikahan Dini pada Komunitas Muslim Madura di Kabupaten Jember, Jurnal Edu-Islamika”, Vol. 3, No.1, 2012, hlm. 96-131. 
Berangkat latar seperti itu, peneliti bermaksud menganalisa lebih lanjut tentang pertunangan usia dini dalam perspektif Kiai di Kecamatan Pragaan, serta menjelaskan pandangan Kiai mengenai kepercayaan masyarakat terhadap mitos tako' sangkal dalam tradisi pertunangan usia dini. Penelitian ini merupakan studi kualitatif dengan jenis studi kasus di Kecamatan Pragaan Kabupaten Sumenep, Jawa Timur Indonesia. Untuk mendapatkan data penelitian, peneliti menggunakan metode observasi partisipan dan wawancara yang kemudian dianalisa dengan menggunakan model Miles and Huberman.

\section{Pertunangan dalam Islam}

Khitbah merupakan salah satu prosesi pelamaran yang diajarkan oleh Rasulullah sebagai aktor hukum utama dalam Islam. Menurut Nor Salam, Nabi Muhammad melakukan pelamaran pada Ummu Salamah. Begitu juga pernikahan Rasulullah dengan Sayyidah Khadijah yang juga diawali dengan khiṭbah. Khadijah, dalam satu riwayat mengutarakan langsung kepada Nabi keinginan untuk menikah dengannya, melalui asisten pribadinya yang bernama Nufaisah binti Munyah agar menyampaikan keinginannya untuk menikah dengan baginda Nabi. ${ }^{4}$

Menurut Djam'annuri, pertunangan secara ilmu fiqih disebut khiţbah yang memiliki arti permintaan. Sedangkan menurut istilah, pertunangan adalah pernyataan atau permintaan dari seorang laki-laki kepada seorang perempuann untuk menikahinya baik dilakukan dengan cara langsung maupun dengan perantara pihak yang dipercayai berdasarkan ketentuan-ketentuan agama. Pengertian serupa diperkuat oleh tokoh lain bahwa khitbah adalah seorang laki-laki memperlihatkan kecintaannya dan bertujuan untuk menikahi seorang wanita yang disukai dan halal untuk dinikahi secara syara.'

Meminang artinya menyatakan permintaan untuk menikah dari seorang laki-laki kepada seorang perempuann atau sebaliknya dengan perantaraan seseorang yang dipercayai. Meminang dengan cara tersebut diperbolehkan dalam Islam terhadap perempuan atau janda yang telah habis masa iddahnya, kecuali perempuan yang masih dalam iddah ba'in, sebaiknya dengan jalan sindiran saja. ${ }^{6}$

\footnotetext{
${ }^{4}$ Nor Salam, "Rekonstruksi Makna Hadis La Yakhtubu al-Rajulu 'Ala Khitbati Akhihi", De Jure: Jurnal Hukum dan Syariah, Vol.8, No. 2, 2016, hlm. 91.

5 Abdul Aziz Muhammad Azzam \& Abdul Wahhab Sayyed Hawwas, Fikih Munakahat: Khitbah, Nikah dan Talak (Jakarta: Amzah, 2009). hlm. 35.

${ }^{6}$ Sulaiman Rasjid, Fiqih Islam (Bandung: Sinar Baru Argensindo, 2000).
} 
Pertunangan merupakan langkah awal dari suatu pernikahan yang memiliki maksud dan tujuan agar masing-masing pihak mengetahui pasangan yang akan menjadi pendamping hidupnya. Hal ini sudah disyariatkan dalam Islam sebelum pelaksanaan akad nikah antara suami dan istri. ${ }^{7}$ Menurut Asbar Tantu, pada umumnya ulama berpendapat bahwa pertunangan tidak wajib. Namun kebiasaan masyarakat dalam praktiknya menunjukkan bahwa pertunangan merupakan pendahuluan yang hampir pasti pelaksanaan perkawinan dilakukan. ${ }^{8}$

Dalam ajaran Islam, salah satu larangan dalam tunangan adalah bertunangan dengan orang yang sudah memiliki tunangan. Ahmad Azhar Basyir menjelaskan bahwa seseorang tidak boleh melakukan pertunangan dengan perempuan yang sedang bertunangan dengan saudaranya sehingga saudaranya meninggalkannya. Pendapat ini disandarkan kepada salah satu hadis Rasulullah yang berbunyi, "Janganlah seseorang dari kamu meminang (wanita) yang dipinang saudaranya, sehingga peminang sebelumnya meninggalkannya atau telah mengizinkannya." 9

Imam Asy-Syafi'i mengatakan bahwa haram hukumnya seseorang meminang wanita yang sudah dipinang oleh orang lain. Hal itu kalau memang si wanita sudah setuju, dan hanya tinggal menunggu akad nilah saja. Menurut mayoritas ulama ahli fikih, keharaman meminang seorang wanita yang sudah dipinang berlaku kalau si wanita memang sudah setuju pada pinangan yang pertama. Atau walinya sudah mengizinkan untuk menikahkan si wanita dengan peminang yang pertama, walaupun si wanita belum memberikan jawaban yang jelas. Menurut para ulama dari mazhab Imam Hanafi, dalam proses musyawarah untuk memberikan jawaban terhadap pinangan, tidak ada larangan sama sekali meminang wanita yang masih dalam status pinangan, meskipun hal itu hukumnya makruh. Bahkan mayoritas ulama menganggap hal itu tidak makruh. Sebab, Fatimah binti Qais pernah dipinang oleh Muaawiyah, oleh Abu Jahm bin Hudzafah, dan juga oleh Usamah bin Zaid. Ketika hal itu ia ceritakan kepada Rasulullah, Beliau memberikan saran kepadanya supaya menolak pinangan Muawiyah serta pinangan Abu Jahm bin Hudzafah. Semula ia menolak saran tersebut, namun akhirnya ia pun setuju. ${ }^{10}$

\footnotetext{
Kautsar, 2006).

Kamil Muhammad Uwaidah, Fiqih Wanita, terj. M Abdul Ghofar (Jakarta: Pustaka Al199-208.

${ }^{8}$ Asbar Tantu, “Arti Pentingnya Pernikahan”, Jurnal Al-Hikmah. Vol. XIV, No. 2, 2013, hlm.

9 Ahmad Azhar Basyir, Hukum Perkawinan Islam, (Yogyakarta: UII Press, 2010).

${ }^{10}$ Ali Syaikh Hafizh Syuaisyi, Kado Pernikahan, (Jakarta: Pustaka Al-Kautsar, 2009).
} 


\section{Tradisi Pertunangan di Madura}

Anak bagi masyarakat Madura dianggap cukup umur apabila sudah akil baligh, baik bagi pihak laki-laki maupun perempuan, maka ia akan segera dinikahkan. Dengan alasan, apabila anaknya sudah berkeluarga, maka beban dan tanggung jawab sebagai orang tua sudah lepas dalam mengasuh anak. ${ }^{11}$ Oleh karenanya, tradisi pertunangan di usia dini biasanya terjadi pada kehidupan keluarga di pedesaan yang mayoritas dari keluarga prasejahtera. Penentuan pertunangan ini dilakukan karena pihak anak perempuan umumnya masih terlalu muda dan masih berada pada masa sekolah, sehingga pihak orang tua tidak langsung menikahkan anak perempuann dengan pihak laki-laki. Dari segi budaya yang berkembang, mereka masih menganut kepercayaan bahwa jika ada seorang laki-laki yang datang untuk melamar anak perempuannya, maka lamaran tersebut harus diterima karena penolakan terhadap sebuah lamaran dapat menyebabkan anak perempuan tidak akan laku lagi.

Seorang anak perempuan yang sudah laku atau sudah ada yang melamar merupakan kebanggaan bagi orang tuanya. ${ }^{12}$ Penentuan jodoh bagi masyarakat Madura berdasarkan tiga pola. Pertama, berdasarkan perjanjian antara orang tua ketika anak masih dalam kandungan dengan pertimbangan unsur pertalian darah. Kedua, berdasarkan kehendak orang tua yang menjodohkan anaknya sejak kecil, baik dengan izin anak-anak maupun tanpa izin mereka. Ketiga, berdasarkan kehendak calon mempelai yang memilih sendiri calon pasangan hidupnya atas restu orang tua. Tetapi dalam hal ini, kebanyakan para orang tua tidak memberikan hak apapun kepada anaknya, sehingga semua hal yang menjadi keputusan orang tua harus dipatuhi oleh anaknya. ${ }^{13}$

\section{Mitos Tako' Sangkal dalam Tradisi Pertunangan di Madura}

Mitos merupakan sistem komunikasi yang mengandung pesan. Dengan ini memungkinkan orang untuk berpandangan bahwa mitos tidak bisa menjadi sebuah objek, konsep, atau ide. Mitos adalah cara penandaan (signification), sebuah bentuk. Atas dasar itu, digunakanlah bahasa, wacana, tuturan, dan lain-lain, untuk menunjuk segala unit atau sistemis yang mengandung makna,

11 Halimatus Sakdiyah \& Kustiawati Ningsih, "Mencegah Pernikahan Dini Untuk Membentuk Generasi Berkualitas (Preventing Early-Age Marriage to Establish Qualified Generation)”, Jurnal Masyarakat, Kebudayaan dan Politik. Vol. 26, No. 1, 2013, hlm. 55-64.

${ }_{12}$ Finda Annesia \& Hari Basuki Notobroto, "Faktor yang Mempengaruhi Perilaku Seksual Pranikah Remaja yang Bertunangan”, Jurnal Biometrika dan Kependudukan, Vol. 2, No. 2, 2013, hlm. 140-147.

${ }^{13}$ Munawara dkk, "Budaya Pernikahan Dini Terhadap Kesetaraan Gender Masyarakat Madura”, JISIP: Jurnal Ilmu Sosial dan Ilmu Politik, Vol. 4, No. 3, 2015, hlm. 426-431. 
baik bentuk verbal ataupun visual. ${ }^{14}$ Menurut Ghazali, mitos dianggap sebagai pengetahuan tentang kata-kata atau ucapan. Kata-kata atau ucapan ini bukan sekadar ucapan biasa, tapi ucapan suci yang mengandung ilham atau wahyu. Keberadaan mitos sangat erat kaitannya dengan adat istiadat dan budaya yang masih bersifat tradisional. Mitos yang telah berlalu tidak mudah untuk disisihkan dari kehidupan sehari-hari, terutama pada masa lalu, karena jika melanggar pantangan pasti akan kualat atau sering disebut pamali. ${ }^{15}$

Madura merupakan salah satu suku masyarakat yang ada di Indonesia. Tentu saja setiap masyarakat adat memiliki kearifan lokal yang khas. Dalam kearifan lokal masyarakat adat, di dalamnya terkandung pemahaman masyarakat tentang adat kebiasaan, tentang manusia, alam, dan yang ghaib. Seluruh kearifan lokal tersebut dihayati, dipraktikkan, diajarkan, dan diwariskan dari satu generasi ke generasi lain yang sekaligus membentuk pola perilaku manusia sehari-hari. ${ }^{16}$ Anak perempuan kebanyakan diperintahkan untuk segera menikah oleh orang tuanya, dengan alasan mematuhi hukum adat-istiadat yang ada sejak jaman nenek-moyang dan anjuran agama. Hal tersebut dikarenakan kekhawatiran orang tua agar anak perempuannya selamat dari mitos perempuan tua, selain juga karena alasan ekonomi juga bagi orangtua untuk segera menikahkan anak perempuannnya, sehingga dengan ini pendidikan untuk anak perempuann tidak dianggap penting. ${ }^{17}$

Berangkat dari kepercayaan terhadap suatu mitos, yang kemudian menjadi kebiasaan, maka dengan begitu hal ini terjadi dan terus bertahan dari generasi ke generasi. Kasus pertunangan anak usia dini sebagaimana yang terjadi di masyarakat Pragaan, dianggap sebagian besar masyarakat tidak bertentangan dengan ajaran Islam. Hal ini mereka sandarkan pada pendapat Kiai Mahmad Aini, da'i Kementerian Agama, yang saat ini bertempat tinggal di Pragaan Laok. Ia menjelaskan bahwa kebiasaan yang terjadi di masyarakat Pragaan, anaknya yang dipertunangkan pada usia dini, hal ini tidak bertentangan dengan Islam. Karena kebiasaan itu dianggap muhkam, sebagaimana kaidah al'ädah muh kamah. Ia menambahkan, muhkam itu dilihat terlebih dahulu tradisinya. Kalau tradisinya jelas keluar dari syariat, maka jelas salah. Akan tetapi, kebiasaan Wacana, 2009).

${ }^{14}$ Roland Barthes, Mitologi. Terj. Nurhadi dan A. Sihabul Millah, (Yogyakarta: Kreasi

15 Adeng Muchtar Ghazali, Antropologi Agama: Upaya Memahami Keragaman Kepercayaan, Keyakian dan Agama, (Bandung: Alfabeta, 2011).

16 Ainurrahman Hidayat, "Ontologi Relasi Dalam Tradisi Budaya Masyarakat Madura”, Jurnal Nuansa, Vol. 9, No. 1, 2012, hlm. 1- 24.

${ }_{17}$ Munawara, dkk, Budaya Pernikahan Dini Terhadap Kesetaraan Gender Masyarakat Madura, JISIP: Jurnal Ilmu Sosial dan Ilmu Politik, Vol, 4 No. 3. 2015, hlm. 427. 
mempertunangkan anak di usia dini, hanya bernilai budaya saja, tidak apa-apa dalam ajaran Islam.

Jadi, cukup jelas bahwa kasus pertunangan anak yang masih usia dini yang terjadi di Pragaan, menurut mayoritas ulama yang ada di sana tidak bertentangan dengan ajaran Islam. Bahkan menurut Kiai Mujammi’ Abdul Musyfi, asal Pragaan Laok, alumni Ummul Qura' University, menjelaskan bahwa istilah "usia dini" hanya ada di masyarakat Indonesia saja, di dalam Islam tidak ada istilah ini. Lebih lanjut ia menjelaskan bahwa Siti Aisyah menikah dengan Rasulullah dalam suatu riwayat ketika umur tujuh tahun, ada yang mengatakan sembilan tahun. Pernikahan usia dini ini ada dalam peraturan Indonesia, akan tetapi kalau dalam peraturan agama Islam, tidak ada. ${ }^{18}$

Namun, pertunangan dini yang dilaksanakan oleh para orang tua di Kecamatan Pragaan, didasari atas rasa takut anaknya akan pamali, yaitu tidak dapat mendapat jodoh. Hal ini yang menurut Kiai Mujammi’ Abdul Musyfi perlu diluruskan sesuai dengan syariat Islam. Ia menambahkan, rasa takut manusia itu tidak bisa dilarang, karena takut itu suasana kejiwaan, namun ketika orang takut terhadap sesuatu harus mempunyai alasan-alasan rasional, termasuk dalam ketakutan mereka terhadap mitos tako' sangkal bagi anaknya jika hendak dipinang orang.

Kebiasaan yang terjadi di Pragaan berkenaan dengan pertunangan anak usia dini, jika ada dasarnya, maka termasuk pada al'-ädah. Namun jika tidak ada dasarnya, maka termasuk kategori asāțir, yaitu hanya sebatas kepercayaan pada mitos saja, tanpa ada dasarnya. Dalam hal ini, dasar yang dimaksud adalah dalil aqli dan dalil naqli. Jadi, kalau sudah tidak ada dasarnya, itu namanya mitos yang dilarang. Seperti dulu, gerhana yang di makan oleh binatang, maka harus memukul pentongan. Selanjutnya berubah, setelah diberikan pendidikan, hal seperti ini hilang dengan sendirinya sesuai dengan pendidikan dakwah, akhirnya masyarakat akan meninggalkannya. Al-'ādah (tradisi) yang dibenarkan dalam Islam adalah yang sesuai dengan syariat Islam.

Menurut Kiai Fattah Syamsuddin, lulusan Al-Azhar Mesir yang bertempat tinggal di Pragaan Laok, dalam pandangan Islam, pertunangan yang terjadi pada usia dini itu sesuai dengan sejarah. Yakni, ketika Nabi Muhammad menikah dengan Aisyah dalam usia tujuh tahun dan berkumpul dengannya pada saat berusia sembilan tahun. Hal ini menurutnya termaktub dalam hadis al-Bukhari. Selain itu, menurut sebagian besar ulama Pragaan, mitos tako' sangkal dalam

\footnotetext{
${ }^{18}$ Wawancara pribadi penulis dengan KH. Mujammi’ Abdul Musfi.
} 
pertunangan dianggap sesuai dengan ajaran Islam. Selama tidak menyalahi tuntunan syariat, maka hal itu boleh-boleh saja. Islam sendiri menilai sebuah mitos yang sudah menjadi tradisi di Masyarakat. Karena dalam Islam, tradisi itu boleh menjadi sandaran hukum, dengan syarat tidak menyalahi hukum syara', dan tidak ada unsur syirik kepada Allah.

Pertunangan yang dilakukan oleh anak usia dini tidak hanya terjadi di masyarakat kecamatan Pragaan saja. Hal serupa juga terjadi di desa Lapa Taman, sebagaimana penelitian Nurmi Ariyantika. ${ }^{19}$ Adapun motif terjadinya pertunangan di kedua tempat tersebut adalah untuk mempererat hubungan kekeluargaan. Selain itu, ada kehawatiran para orang tua mereka, yang takut berpisah jauh dengan anak-anaknya, sehingga solusinya adalah dengan cara mempertunangkan anak-anaknya, demi menjalin hubungan kekeluargaan yang lebih dekat.

Namun, mayoritas ulama di daerah ini menganjurkan untuk tidak menikahi keluarganya sendiri. Hal ini mereka sandarkan pada pendapat Syaikh Abdul Qadir Jailani, yakni sebelum menikah, agar memilih calon istri yang baik, bukan dari keluarga sendiri, masih perawan dan dikenal subur. Berkenaan dengan disyaratkannya orang lain, bukan keluarganya sendiri, dimaksudkan agar tidak terjadi perpecahan dan permusuhan di dalam kelurga yang dapat mengakibatkan putusnya tali silaturahmi, karena Rasulullah memerintahkan untuk senantiasa menghubungkan tali silaturahmi. ${ }^{20}$

Selanjutnya, Kiai Fattah Syamsuddin, doktor bidang hadis dari Universitas Kebangsaan Malasyia mengatakan bahwa dalam pertunangan, tidak mesti harus mendapatkan restu dari orang tua. Namun, jika pertunangan itu berlanjut kepada perkawinan, maka orang tuanya wajib ada untuk menjadi wali. Kiai Fattah Syamsuddin menguraikan bahwa dalam pertunangan hanya ada dua persyaratan dalam melamar, yaitu: wanita itu tidak dipinang oleh orang lain, dan syarat yang kedua adalah mendapat persetujuan dari pihak wanita.

Pendapat senada juga disampaikan oleh ahli hadis yang lain di Kecamatan Pragaan yaitu Kiai Mahmad Aini, yang merupakan alumni Universitas Islam Madinah. Ia menjelaskan bahwa sebetulnya orang tua tidak punya hak untuk memaksa anak ketika dia ada yang minta untuk tunangan. Orang tua harus setuju, walaupun dalam madzhab Syaf'i, ada istilah wali mujbir, sehingga seorang wali

19 Nurmi Ariyantika, Perilaku Calon Pengantin Pasca Perayaan Peminangan (Ghabai Bhakalan) Perspektif Teori Perilaku Sosial (Studi di Desa Lapa Taman Kec Dungkek Kab Sumenep), UIN Maulana Malik Ibrahim Malang, 2016. 156.

20 Abdul Qadir Jailani, Syaikh. Fiqih Tasawuf, (Bandung: Pustaka Hidayah, 2006), hlm. 
dari anak yang masih kecil boleh menikahkannya. Lebih lanjut ia menjelaskan bahwa pada zaman Rasulullah, ada seorang anak dilamar oleh sepupunya, tapi tidak mau, akhirnya dia melapor kepada Rasulullah. Kemudian orang tuanya dipanggil oleh Rasulullah, dan akhirnya anak tersebut diberi wewenang untuk mempelajari calon yang dipilihkan oleh orang tuanya. Walaupun pada akhirnya, anak tersebut bersedia. Namun pelajaran yang dapat dipetik dari kasus ini adalah bahwa dalam masalah ini, orang tua itu tidak semena-mena dalam memaksa anaknya. Perlu adanya musyawarah untuk mencari jalan terbaik, bagaimana anak tidak dirugikan. Dengan kata lain, anak tidak bisa dengan mudah dikategorikan durhaka, karena anak masih diberi hak oleh Rasulullah.

Muhammad Kudhori menambahkan beberapa pendapat dari hadis Nabi Muhammad. Ia menyebutkan, setidaknya ada empat riwayat hadis hak perempuan dalam memilih suaminya. Pertama adalah hadis riwayat al-Bukhari dengan redaksi: "bahwa seorang perempuan dari anak Jafar merasa ketakutan walinya menikahkannya, sedangkan dia tidak suka, maka ia segera mengutus seseorang menemui dua shaikh dari kalangan Anshar, yaitu Abd al-Rahman dan Mujammi, dua anak Jariyah. Maka keduanya berkata; Janganlah khawatir, karena Khansa binti Khidham pernah dinikahkan ayahnya, sedang dia tidak suka, maka Nabi menolak pernikahannya." Kedua, adalah hadis riwayat Bukhari dengan redaksi: "Sesungguhnya pada diri Barirah terdapat tiga sunnah. Salah satunya ia telah dimerdekakan dan diberi tawaran untuk memilih terhadap suaminya."

Ketiga adalah hadis riwayat Bukhari dengan redaksi: "suami Barirah adalah seorang budak yang bernama Mughith. Sepertinya aku melihat ia bertawaf di belakangnya seraya menangis, hingga air matanya membasahi jenggot”. Maka Nabi bersabda: "Wahai Abbas, tidakkah kamu takjub akan kecintaan Mughith terhadap Barirah, dan kebencian Barirah terhadap Mughith? Akhirnya Nabi pun berkata kepada Barirah: "Seandainya kamu mau merujuknya kembali." Barirah bertanya: "Wahai Rasulullah, apakah Anda menyuruhku?” Beliau menjawab: "Aku hanya menyarankan." Akhirnya Barirah pun berkata: "Sesungguhnya aku tak berhajat sedikit pun padanya. Keempat, adalah hadis riwayat Muslim dengan redaksi: "dari Aishah istri Nabi bahwa dia berkata: "Dalam kasus Barirah, ada tiga sunnah (salah satu di antaranya) yaitu dia diberi pilihan atas suaminya ketika dia dibebaskan."

Hadis-hadis di atas mempunyai kandungan makna bahwa seorang perempuan mempunyai kebebasan secara penuh untuk memilih suaminya, tanpa adanya paksaan dari orang tuanya. Hadis di atas secara jelas menegaskan bahwa urusan memilih suami secara penuh merupakan hak seorang perempuan, bukan 
berdasarkan keputusan, apalagi paksaan dari orang tua. Hal ini ditegaskan oleh perkataan perempuan pada hadis Buraydah bahwa "para bapak tidak mempunyai keputusan sama sekali dalam masalah ini." Apa yang diucapkannya pada hadis di atas diketahui oleh Nabi dan dibiarkan. Hal ini menjadi ketetapan (taqrîr) dari Nabi. Perempuan juga berhak menentukan untuk melanjutkan pernikahan atau membatalkannya, setelah dinikahkan oleh walinya dengan orang yang tidak dicintainya.

Selain itu, Muhammad Kudhori juga mengutip sebuah hadis riwayat alBukhari dan Muslim:

Dari Abdullah bin Masud dia berkata: "Saya bertanya kepada Rasulullah Saw., amal apakah yang paling utama?" Beliau menjawab: Salat pada waktunya. Aku bertanya lagi: "Kemudian apa lagi? Beliau menjawab: "Berbakti kepada kedua orang tua. Aku bertanya lagi: Kemudian apa lagi? Beliau menjawab: "Berjuang di jalan Allah. Kemudian aku tidak menambah pertanyaan lagi karena semata-mata menjaga perasaan Beliau." ${ }^{21}$

Ketika mengomentari hadis ini, ia mengutip pendapat al-Maraghi, yang menjelaskan bahwa berbakti kepada kedua orang tua adalah menghormati keduanya dengan penghormatan yang dilandasi cinta kasih dan kemuliaan, bukan menghormati karena rasa takut. Dengan demikian, menurut al-Maraghi, kedua orang tua tidak boleh menghukumi urusan anak yang bersifat khusus, lebih-lebih orang tua tidak boleh menikahkan anaknya dengan orang yang tidak dicintainya atau melarangnya hijrah untuk menuntut ilmu yang bermanfaat, mencari harta, kedudukan dan lain sebagainya.

Lebih kanjut, ia juga menjelaskan bahwa Muhammad bin Shalih alUtsaymin menyatakan, berbakti kepada kedua orang tua adalah berbuat baik kepada keduanya dengan harta, badan, kedudukan termasuk juga dengan ucapan dan perbuatan. Berbakti kepada kedua orang tua dapat dilakukan dengan melayani keduanya secara baik, sesuai dengan kebiasaan yang berlaku. Namun ketika orang tua menyuruh anak untuk melakukan sesuatu yang haram, maka seorang anak tidak boleh menurutinya. Dalam kasus seperti ini, mencegah orang tua melakukan sesuatu yang haram, merupakan bagian dari berbakti kepada kedua orang tua. Hal ini berdasarkan sabda Nabi Saw: Tolonglah saudaramu baik ia zalim atau dizalimi." Ada seorang laki-laki bertanya: "Ya Rasulullah, saya maklum jika ia dizalimi, namun bagaimana saya menolong padahal ia zalim?

\footnotetext{
${ }^{21}$ Muhammad Kudhori, "Hak Perempuann dalam Memilih Suami (Telaah Hadis Ijbar Wali)”, Jurnal al-Ihkam, Vol. 12, No. 1, 2017, hlm. 1-23.
} 
Nabi menjawab: "Engkau mencegahnya atau menahannya dari kezaliman, itulah cara menolongnya."

Berdasarkan hadis di atas, mencegah orang tua ketika melakukan sesuatu yang diharamkan, termasuk salah satu bentuk berbakti dan berbuat baik kepada keduanya. Dapat ditarik sebuah kesimpulan bahwa ketika seorang anak tidak mematuhi perintah orang tua yang akan menikahkannya dengan orang yang tidak disukainya, maka hal itu bukanlah merupakan bentuk durhaka kepada orang tua. Justeru sebaliknya, tidak mematuhi orang tua dalam hal ini, kemudian menasehatinya dengan baik, agar orang tua tidak melakukan pemaksaan untuk menikah dengan orang yang tidak dicintainya, merupakan salah satu bentuk berbakti kepada orang tua. Sebaliknya, seorang anak yang mematuhi perintah orang tua yang akan menikahkannya dengan orang yang tidak dicintainya, tidak bisa dikatakan sebagai bentuk berbakti kepada orang tua, karena kepatuhan anak tersebut bukan atas dasar cinta kasih dan kemuliaan, sebagaimana yang diungkapkan al-Maraghi, melainkan karena lebih berdasar pada rasa takut kepada kedua orang tua dan keterpaksaan.

Sebenarnya, perbedaan pendapat antara anak dan orang tua itu sudah biasa terjadi, termasuk dalam persoalan penentuan calon tunangan. Namun, jika terjadi perbedaan pendapat antara anak dan orang tuanya dalam hal calon lelaki yang akan ditunangkan dengannya, maka solusi yang paling tepat, adalah perlu adanya komunikasi yang baik antara keduanya. Hal ini sebagaimana disampaikan oleh Kiai Mujammi' bahwa bahwa orang tua tidak bisa memaksa anak secara mutlak apa yang dikehendaki oleh anaknya. Anak juga demikian, perlu membangun komunikasi yang baik dengan orang tuanya, maka di sini akan ada titik temu dari persoalan tersebut. Perlu adanya penyampaian alasanalasan rasional, baik dari pihak orang tua maupun anak. Walaupun rida orang tua penting dalam hal pertunangan anaknya, akan tetapi orang tua harus melandasi dengan alasan-alasan yang rasional, bukan karena motivasi materialistis. Jika orang tua memandang materinya, kemudian memaksakan anaknya dan anaknya tidak mau, maka anak punya hak untuk menolak. Tentu cara menolaknya harus dengan baik, bukan dengan komunikasi tidak baik, serta disampaikan dengan cara yang baik pula.

Namun demikian, kasus yang ada di masyarakat Pragaan menunjukkan bahwa anak perempuan yang ditunangkan oleh orang tuanya itu masih tergolong masih kecil, atau masih usia dini. Beberapa ulama menyandarkan pendapatnya kepada hadis nabi Muhammad, salah satu contohnya adalah pendapat Ibn Taymiyah yang menegaskan bahwa wilayah ijbār bagi seorang 
bapak hanya berlaku bagi perempuan yang masih kecil (belum baligh). Adapun perempuan yang sudah baligh, maka tak seorang pun dari walinya yang berhak untuk memaksanya. Hal ini berdasarkan hadis Nabi: "Perempuan tidak boleh dinikahkan hingga dimintai izin, dan janda tidak boleh dinikahkan hingga dimintai persetujuannya." Ada yang bertanya; "Ya Rasulullah, bagaimana tanda izinnya?" Nabi menjawab: “Tandanya diam.” Fenomena yang terjadi di Kecamatan Pragaan, penyebab terjadinya pertunangan dini dikarenakan ketidakberdayaan dan ketidaktahuan anaknya tentang arti pertunangan. Tentu kejadian semacam ini tidak hanya terjadi di Pragaan saja, tetapi juga terjadi di tempat lain di Madura, bahkan mungkin di daerah lain di Indonesia.

Hal ini selaras dengan apa yang dihasilkan Masyithah Mardhatillah bahwa dalam tradisi perjodohan, di mana perempuann Madura umumnya 'diharuskan' menerima, menjalani sekaligus melestarikan berbagai tradisi yang telah mengakar di masyarakat. Mereka tidak sepenuhnya bebas memilih kapan dan dengan siapa mereka menikah, serta cenderung menunggu lamaran dari pihak laki-laki atau inisiatif orang tua, perihal perjodohan dengan calon yang mungkin belum dikenal dan atau tak sesuai dengan kriteria yang didambakan. Kekhawatiran seorang perempuan akan menjadi perempuan tua dan ta' paju lake (tidak ada lelaki yang melamar atau mau menikahi) bisa dibilang merupakan faktor utama tingginya angka pernikahan dini bagi perempuann Madura. Sebagian masyarakat Madura masih memercayai bahwa lamaran pertama terhadap si perempuan akan menjadi pamali jika ditolak. Tak heran, perjodohan dan atau pertunangan perempuan Madura, tidak hanya dimulai ketika sang anak memasuki usia remaja, akan tetapi sejak masa kanak-kanak, bahkan ketika masih dalam kandungan, meski secara umum perjodohan biasanya diselenggarakan setelah anak perempuan mengalami datang bulan (haid) pertama. ${ }^{22}$

Berbicara soal persetujuan orang tua dalam pertunangan anak, juga berkenaan dengan tingkat kepatuhan seorang anak kepada orang tuanya. Moh Hefni mengatakan bahwa masyarakat Madura dikenal sebagai komunitas yang patuh dalam menjalankan ajaran Islam, hingga saat ini, salah satu budaya yang berkembang dalam masyarakat Madura adalah penghormatan yang tinggi kepada pilar-pilar penyangga kebudayaan Madura, yakni bhupa'-bhabhu'-ghuru-rato, yang dalam Bahasa Indonesia berarti bapak-ibu-guru (kyai) rato (pemerintah). Konsep bhupa'-bhabhu'-ghuru-rato merupakan konstruksi kehidupan kolektif yang berlangsung selama periode sejarah yang relatif panjang. Ia dihasilkan oleh,

${ }^{22}$ Masyithah Mardhatillah, "Perempuann Madura sebagai Simbol Prestise dan Pelaku Tradisi Perjodohan”, Jurnal Musawa, Vol 13, No. 2, 2014, hlm. 167-178. 
dan sekaligus menghasilkan kehidupan sosial, sehingga menjadi sebuah struktur kehidupan sosial (structuring structure). Dalam kaitan ini, kepatuhan kepada orang orang tua diberikan, karena terdapat struktur religio-kultural yang berupa kewajiban agama dan budaya, karena mereka telah melahirkan dan mengasuh hingga dewasa. ${ }^{23}$

Menurut Kiai Ghozi Mubarok, dalam hal pertunangan, seorang ayah boleh memaksa anaknya untuk ditunangkan dengan seorang laki-laki pilihannya. Dan juga, seorang ayah berhak menolak calon yang diajukan oleh anaknya kepadanya. Karena khitbah itu bagian dari perjalanan menuju nikah, maka restu seorang ayah menjadi syarat dalam pertunangan. Ketika seorang anak perempuan tidak setuju dengan pilihan orang tuanya, ia bisa negoisasi dengan orang tua, tapi tidak dengan perkataan yang kasar. Hal ini senada dengan pendapat Kiai Bastami Thibyan dari Pondok Pesantren Al-Amien Prenduan yang menguraikan bahwa anak perempuan yang menolak perintah orang tuanya dalam pemilihan tunangannya dapat dikategorikan anak durhaka. Karena orang tua dalam hal ini masuk kategori wali mujbir. Namun orang tua memiliki batasan untuk memaksa anaknya dalam pertunangan, jika calon keduanya masuk kategori kufu'. Begitu juga jika seorang anak memiliki calon, yang tidak disetujui oleh kedua orang tuanya, hal itu juga masuk kategori durhaka.

Pendapat Kiai Ghozi dan Kiai Bastami di atas, sesuai dengan pendapat Kiai Syuja, yang menambahkan bahwa taat pada sesuatu yang bernilai maksiat dilarang dalam agama. Sedangkan kewajiban patuh seorang anak kepada orang tua jelas di dalam ayat al-Qur'an. Menurut Kiai Syuja, jika seorang anak memiliki calon sendiri, namun kedua orang tuanya tidak menerima hubungan itu, maka dalam hal ini ada dua pilihan, yaitu jika orang tua punya pilihan yang lebih hebat dan lebih $k u f u$ ', maka anak perempuann wajib mengikuti pilihan orang tua. Kalau terpaksa anak perempuan tersebut kawin dengan pilihan sendiri, yang ke kufu'annya kalah dengan pilihan orang tuanya, maka perkawinannya tidak sah. Dengan begitu, dalam tunangan membutuhkan rida orang tua.

Dalam pertunangan, tiga tokoh agama di Pragaan tersebut mengkategorikan orang tua anak yang akan bertunangan sebagai wali mujbir. Dalam bahasa Arab, ijbār bermakna pemaksaan atau mengharuskan dengan memaksa dan keras. ${ }^{24}$ Jadi, jika kemudian orang tua bagi anak yang hendak

${ }^{23}$ Moh Hefni, "Bhuppa'-Bhabu'-Ghuru-Rato (Studi Konstruktivisme-Strukturalis tentang Hierarki Kepatuhan dalam Budaya Masyarakat Madura)”, Jurnal Karsa, Vol. XI, No. 1, 2007, hlm. $1-16$.

${ }^{24}$ Ahmad Warson Munawwir, Al-Munawwir: Kamus Arab Indonesia, (Yogyakarta: Pondok Pesantren Al-Munawwir Krapyak, 1984), hlm. 164. 
bertunangan dianggap sebagai wali mujbir, maka orang tua berhak untuk memaksakan kehendaknya untuk mempertunangkan anaknya, walaupun tidak atau tanpa izin dari anak perempuannya. Hal ini karena dianggap sebagai hak ijbār dari seorang wali.

Dalam kitab al-Jāmi' al-șahịh, Muslim menulis bab yang berjudul “Tazwìj al-Abb al-Bikr al-saghirah”. Dalam bab ini dijelaskan tentang kebolehan seorang bapak menikahkan anak perempuannya yang masih kecil. Kemudian Muslim menampilkan hadis sebagai berikut:

Dari Aisyah berkata: Rasulullah menikahiku waktu aku berumur enam tahun, dan memboyongku (membina rumah tangga denganku) ketika aku berusia sembilan tahun." Aisyah berkata; Sesampainya di Madinah, aku jatuh sakit selama sebulan, hingga rambutku rontok. Setelah sembuh, Ummu Ruman mendatangiku, ketika itu aku sedang bermain-main bersama kawan-kawanku, lantas dia memanggilku, dan aku mendatanginya, namun aku tidak tahu apa yang dia inginkan dariku. Kemudian dia memegang tanganku dan membawaku sampai ke pintu rumah, (aku terengah-engah) sambil menarik nafas sehingga nafasku lega kembali. Kemudian aku dibawa masuk ke dalam rumah, tiba-tiba di sana telah menunggu beberapa wanita Ansar. Mereka mengucapkan selamat dan kebaikan kepadaku, lantas Ummu Ruman menyerahkanku kepada mereka, akhirnya mereka membersihkan kepalaku dan mendandaniku, pada waktu dhuha, betapa terkejutnya aku ketika melihat Rasulullah muncul di tempat kami, kemudian mereka menyerahkanku kepada Beliau".

Di kalangan mazhab Syaf'i, kebolehan menikahkan anak perempuan (baik yang masih kecil atau yang sudah baligh) tanpa sepengetahuan anak, hanya berlaku pada wali mujbir. Yaitu wali yang boleh memaksa anak perempuannya untuk dinikahkan pada orang lain (wali mujbir hanya terbatas pada ayah dan kakek). Hal ini berdasarkan pada sebuah hadis yang diriwayatkan oleh Ibn Abbas bahwa Rasulullah bersabda: "Janda lebih berhak terhadap dirinya daripada walinya (dalam nikah) dan perempuan bapaknya dianjurkan untuk minta persetujuannya." Dalam riwayat lain: "Untuk perempuan, bapaknya yang menikahkannya”. Bagi Masturiyah Sa'dan, wali mujbir, menurut Imam Syafi'i terdiri dari ayah, kakek dan terus ke atas. Dasar argumen yang digunakan oleh Imam Syafi'i adalah hadis Nabi, "Perempuann janda lebih berhak daripada dirinya sendiri dibandingkan walinya, sedangkan perempuann yang masih perempuan dinikahkan oleh ayahnya".

\footnotetext{
${ }^{25}$ Masturiyah Sa'dan, "Menakar Tradisi Kawin Paksa di Madura dengan Barometer HAM", Jurnal Musawa, Vol. 14, No. 2, 2015, hlm. 148.
} 
Dalam al-Fiqh 'Ala al-Madzhib al-Ar'ba'ah, para fuqaha membagi menjadi dua macam wali. Pertama, wali mujbir, yaitu seseorang wali yang memiliki hak penuh untuk memaksa anak perempuann yang berada di bawah perwaliannya, untuk melakukan pernikahan, meskipun anak tersebut tidak menyetujuinya. Kedua, wali ghairu mujbir, yaitu seorang wali yang tidak memiliki hak penuh untuk memaksa dan mengawinkan perempuan yang berada di bawah perwaliannya, tanpa seizin perempuan tersebut. Orang yang termasuk wali mujbir, adalah bapak, kemudian kakek dari garis bapak, demikian menurut Imam Syafi'i. Pendapat ini berbeda dengan yang dikemukakan Imam Malik dan Imam Ahmad ibn Hanbal. Menurut mereka, yang termasuk wali mujbir hanyalah bapak, sementara kakek tidak. Sedangkan orang yang termasuk wali ghairu mujbir, menurut mazhab selain Hanafi, adalah seluruh orang yang termasuk dalam kategori aṣābah dalam hukum waris, kecuali bapak dan kakek, yang mengawinkan seorang perempuann yang berada di bawah perwaliannya, perempuan ataupun janda.

Namun demikian, bapak atau kakek bisa juga menjadi wali ghair mujbir jika perempuan yang berada di bawah perwaliannya itu berstatus janda. Sementara Imam Hanafi memiliki konsep yang berbeda. Menurutnya, bapak atau kakek tetap menjadi wali ghairu mujbir sekalipun perempuan yang berada di bawah perwaliannya itu masih berstatus perawan atau sudah janda. Hal senada juga dapat dilihat dari keputusan Nahdhatul Ulama berkenaan dengan wali mujbir untuk mengawinkan anak perempuann yang sudah dewasa dengan pemuda yang sepadan. Menurut hasil keputusan ini, wali mujbir boleh memaksa anaknya walaupun dalam koridor makruh, dan dengan syarat asal tidak ada kemungkinan akan timbul bahaya. ${ }^{26}$

\section{Kesimpulan}

Setelah dilakukan pembahasan, dapat disimpulkan bahwa mayoritas kiai di Kecamatan Pragaan menyepakati bahwa tradisi pertunangan dini yang ada di daerahnya tidak bertentangan dengan syariat Islam. Walaupun dalam pelaksanaan, tradisi tersebut sering terjadi ketidaksamaan pendapat antara anak dan orang tuanya. Terdapat dua pendapat kelompok kiai yang ada di kecamatan ini. Kelompok pertama mengatakan bahwa pertunangan anak perempuan tidak membutuhkan restu orang tua, dengan kata lain, anak memiliki kebebasan memilih. Sedangkan kelompok kedua berpendapat bahwa anak yang menolak

${ }^{26}$ Djamaluddin Miri, Ahkamul Fuqaha: Solusi Problematika Aktual Hukum Islam, Keputusan Muktamar Munas dan Konbes Nahdlatul Ulama (1926-1999 M), (Surabaya: Lajnah Ta’lif Wan Nasyr NU Jawa Timur kerjasama Penerbit Diantama, 2005), hlm. 82. 
perintah orang tua dalam bertunangan dihukumi sebagai anak durhaka, yang dalam hal ini restu orang tua menjadi syarat bagi pertunangan anak. Secara umum, kiai yang ada di Pragaan, tidak satupun yang menyalahkan mitos sangkal dalam tradisi pertunangan anak usia dini. Bagi mereka, mitos sangkal yang tidak menyalahi syariat dianggap sebagai kebiasaan atau tradisi, yang oleh mereka dikategorikan sebagai al-'ādah. 


\section{DAFTAR PUSTAKA}

Ali, Atabik \& Ahmad Zuhdi Muhdlor. Kamus Kontemporer Arab Indonesia. Yogyakarta: Multi Karya Grafika. 2003.

Annesia, Finda \& Notobroto, Hari Basuki. "Faktor yang Mempengaruhi Perilaku

Seksual Pranikah Remaja yang Bertunangan”. Jurnal Biometrika dan Kependudukan, Vol. 2, No. 2. 2013.

Ariyantika, Nurmi. Perilaku Calon Pengantin Pasca Perayaan Peminangan (Ghabai Bhakalan) Perspektif Teori Perilaku Sosial (Studi di Desa Lapa Taman Kec Dungkek Kab Sumenep). UIN Maulana Malik Ibrahim Malang. 2016.

Assegaf, Abd Rachman. Desain Riset Sosial-Keagamaan: Pendekatan IntegratifInterkonektif. Yogyakarta: Gama Media. 2007.

Azzam, Abdul Aziz Muhammad \& Hawwas, Abdul Wahhab Sayyed. Fikih Munakahat: Khitbah, Nikah dan Talak. Jakarta: Amzah. 2009.

Barthes, Roland. Mitologi. terjemahan: Nurhadi dan A. Sihabul Millah. Yogyakarta: Kreasi Wacana. 2009.

Basyir, Ahmad Azhar. Hukum Perkawinan Islam. Yogyakarta: UII Press. 2010.

Fatmawati, Erma. "Pernikahan Dini Pada Komunitas Muslim Madura di Kabupaten Jember”. Jurnal Edu-Islamika. Vol. 3 No.1. 2012.

Ghazali, Adeng Muchtar. Antropologi Agama: Upaya Memahami Keragaman Kepercayaan, Keyakian dan Agama. Bandung: Alfabeta. 2011.

Hefni, Moh. "Bhuppa'-Bhabu'-Ghuru-Rato (Studi Konstruktivisme-Strukturalis tentang Hierarki Kepatuhan dalam Budaya Masyarakat Madura)". Jurnal Karsa, Vol. XI. No. 1. 2007.

Hidayat, Ainurrahman. "Ontologi Relasi Dalam Tradisi Budaya Masyarakat Madura”. Jurnal Nuansa, Vol. 9 No. 1.2012.

Jailani, Abdul Qadir, Syaikh. Fiqih Tasawuf. Bandung: Pustaka Hidayah. 2006.

Kudhori, Muhammad. "Hak Perempuann dalam Memilih Suami (Telaah Hadis Ijbar Wali)”. Jurnal al-Ihkam. Vol. 12 No. 1. 2017.

Mardhatillah, Masyithah. "Perempuann Madura sebagai Simbol Prestise dan Pelaku Tradisi Perjodohan”. Jurnal Musawa, Vol 13, No. 2. 2014.

Miri, Djamaluddin. Ahkamul Fuqaha: Solusi Problematika Aktual Hukum Islam, Keputusan Muktamar Munas dan Konbes Nahdlatul Ulama (1926-1999 
M). Surabaya: Lajnah Ta'lif Wan Nasyr NU Jawa Timur kerjasama Penerbit Diantama. 2005.

Munawara, dkk. "Budaya Pernikahan Dini Terhadap Kesetaraan Gender Masyarakat Madura”. JISIP: Jurnal Ilmu Sosial dan Ilmu Politik, Vol, 4 No. 3. 2015.

Munawwir, Ahmad Warson. Al-Munawwir: Kamus Arab Indonesia. Yogyakarta:

Pondok Pesantren Al-Munawwir Krapyak. 1984.

Nur, Djaman. Fiqih Munakahat. Semarang: Dina Utama. 1993.

Rasjid, Sulaiman. Fiqih Islam. Bandung: Sinar Baru Argensindo. 2000.

Sa'dan, Masturiyah. "Menakar Tradisi Kawin Paksa di Madura dengan Barometer HAM”. Jurnal Musawa, Vol. 14, No. 2. 2015.

Sakdiyah, Halimatus \& Ningsih, Kustiawati. "Mencegah Pernikahan Dini Untuk Membentuk Generasi Berkualitas (Preventing Early-Age Marriage to Establish Qualified Generation)”. Jurnal Masyarakat, Kebudayaan dan Politik. Vol. 26 No. 1.2013.

Salam, Nor. "Rekonstruksi Makna Hadis La Yakhtubu al-Rajulu 'Ala Khitbati Akhihi”. De Jure: Jurnal Hukum dan Syari'ah, Vol.8 No. 2. 2016.

Syuaisyi, Ali Syaikh Hafizh. Kado Pernikahan. Jakarta: Pustaka Al-Kautsar. 2009.

Tantu, Asbar. "Arti Pentingnya Pernikahan”. Jurnal Al-Hikmah. Vol. XIV. No. 2. 2013.

Uwaidah, Kamil Muhammad. Fiqih Wanita. terjemahan: M Abdul Ghofar. Jakarta: Pustaka Al-Kautsar. 2006. 
